\title{
Diagnosis of Cardiovascular Disease in Patients with Chronic Kidney Disease
}

\author{
Peter A. McCullough Hadeel Assad \\ St. John Providence Health System, Providence Hospital and Medical Centers, Providence Park Heart Institute, \\ Novi, Mich., USA
}

Key Words

Chronic kidney disease $\cdot$ Cardiovascular disease $\cdot$ Early diagnosis

\begin{abstract}
The major forms of cardiovascular disease including coronary atherosclerosis, valvular disease, myocardial dysfunction, and arrhythmias are observed either alone or in combination in a large fraction of patients with chronic kidney disease (CKD). As CKD progresses, these cardiovascular conditions become more prevalent and severe. The clinical implications of combined heart and kidney disease include challenges in diagnosis and management. In addition, the terminal events in CKD commonly involve one of these four domains of cardiovascular disease. This paper will explore the issue of early diagnosis of heart disease in patients with CKD with the major goal being early intervention to lessen the impact of this comorbidity.
\end{abstract}

Copyright $\odot 2012$ S. Karger AG, Basel

\section{Introduction}

Over the past several decades, there has been a growing appreciation for the association between chronic kidney disease (CKD) and cardiovascular disease (CVD). As a general proxy at the time of this writing for this groundswell of interest, a PubMed search on the intersection of CKD and CVD retrieved 22,268 citations of which 1,678 were listed as clinical trials or discussions of trials, and 61 were indicated to be guidelines or summaries of such documents. Four major domains of CVD are heavily influenced by CKD and include atherosclerosis, valvular disease, myocardial dysfunction, and arrhythmias [1].

The epidemiology of CKD and CVD share a 'common soil' of risk factors, which include older age, hypertension, diabetes mellitus, obesity, and smoking [2]. For CKD, low birth weight; family history of CKD; AfricanAmerican, Native American, and Hispanic ethnicities; microalbuminuria; and anemia appear to be unique risk predictors separate from traditional CVD risk factors [35]. For CVD, family history of CVD, dyslipidemia, and certain measured factors reflecting adiposity (IL-6, highsensitivity C-reactive protein) and immune cell signaling or activity (lipoprotein-associated phospholipase $\mathrm{A}_{2}$, my-

Peter A. McCullough, MD, MPH, FACC, FACP, FAHA, FCCP

St. John Providence Health System, Providence Hospital and Medical Centers Providence Park Heart Institute, 47601 Grand River Avenue, Suite B-125 Novi, MI 48374 (USA)

Tel. +1 248465 5485, E-Mail peteramccullough@gmail.com 
eloperoxidase) have been shown to be independently associated with CVD and not necessarily CKD. Thus, risk factor assessment of CKD and CVD can largely be complemented by gathering information relevant to both diseases and understanding that when a patient lies in the intersection of CKD and CVD, the risks of cardiac and all-mortality are very high [6].

Patients with combined CKD and CVD, in general, should have relative risk reductions for consequences of both organ system diseases with standard prevention measures including smoking cessation, dietary sodium reduction, weight reduction, blood pressure control, glycemic control, and lowering low-density lipoprotein cholesterol [7-9]. However, the conclusive evidence to support modification of each risk factor for combined CKD and CVD is either controversial or lacking in virtually every area. Thus, it is important to diagnose CVD in CKD patients in order to provide specific treatments with more precise goals of care [10].

\section{Coronary Artery Disease}

Coronary atherosclerosis is the most common form of CVD outside of hypertension according to the American Heart Association. It has been shown that neonatal renal disease has been associated with the very early signs of atherosclerosis at the time of birth. The presence of CKD, independent of other CVD risk factors, appears to accelerate the atherosclerotic process, including the gradientdependent deposition of low-density lipoprotein particles, recruitment of monocytes, upregulation of adhesion molecules, ingress of monocytes and conversion to macrophages and foam cells, mobilization of vascular smooth muscle cells, breakdown of the elastic lamina, and development of an atheroma which expands both towards the lumen and outward towards the adventitia $[11,12]$.

The most prominent component of atherosclerosis influenced by CKD is calcification. It has been shown that calcium initially deposits in the subendothelial space in a passive fashion and accounts for a minor degree of the overall calcium in an atherosclerotic plaque [13]. The majority of anatomic and visible calcium by imaging in atherosclerosis is the result of osteoblastic conversion of smooth muscle cells and the deposition of calcium hydroxyapatite crystals in the extracellular matrix. Phosphate appears to be an important stimulator of the vascular smooth muscle cell to both undergo osteoblastic deposition and deposit calcium. Thus, reducing the phosphate load on the body may be a strategy to lim-

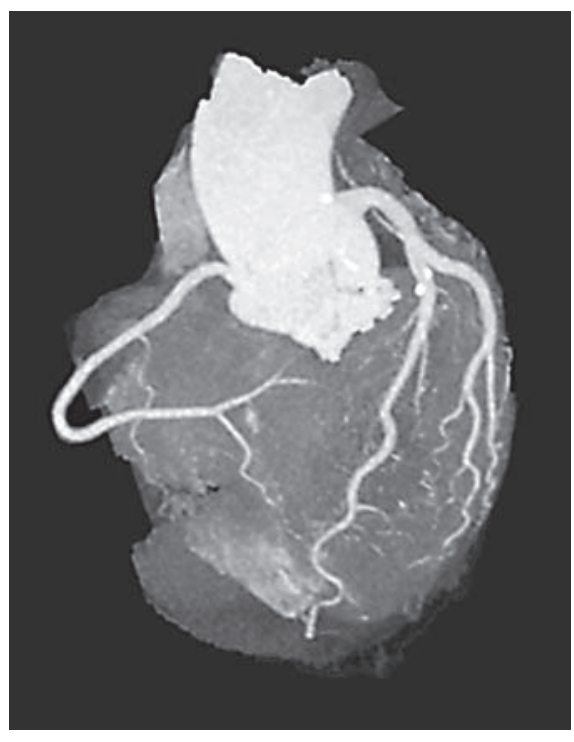

Fig. 1. Cardiac computed tomographic angiography with calcium score in a patient with CKD with an uninterpretable stress test result demonstrating coronary calcification in the wall of the proximal left anterior descending artery without significant luminal obstruction. The calcium score was 125 Agatston units.

it the calcification process; however, this hypothesis has not been subjected to randomized placebo controlled trials.

A listing of selected cardiac diagnostic studies that can be obtained in patients with CKD is given in table 1 . It is important to recognize that coronary calcification seen on computed tomographic studies is atherosclerosis anatomically and not a manifestation of passive calcification previously thought to be Mönckeberg's sclerosis (fig. 1). Vascular calcification is a proxy for a greater burden of atherosclerosis, reduced vascular compliance, and more mature and stable plaques [14]. Thus, coronary calcification can be used to diagnose coronary artery disease in patients with CKD. When the coronary calcium score (either volumetric or Agatston) is $>400$ units, then the probability of at least one significant $(>70 \%)$ lesion resulting in reduced myocardial blood flow with stress is $\geq 80 \%$. Thus, if a calcium score is known at the time of evaluation and the score is $>400$, it is reasonable to move forward with a functional study including stress-imaging (exercise or pharmacologic stress echo, exercise or pharmacologic stress nuclear scintigraphy). Otherwise, in an asymptomatic patient, there is no clear-cut mandate to perform screening stress testing or other imaging procedures. 
Table 1. Select diagnostic tests for CVD in patients with CKD

\begin{tabular}{|c|c|}
\hline Test & Comment \\
\hline 12-lead electrocardiogram & $\begin{array}{l}\text { Should be done yearly, evaluates baseline rhythm, presence of Q-waves, chamber enlarge- } \\
\text { ments, left ventricular hypertrophy }\end{array}$ \\
\hline $\begin{array}{l}\text { Functional imaging } \\
\text { Exercise stress echocardiography } \\
\text { Exercise stress nuclear scintigraphy } \\
\text { (Tc-99 sestamibi or Tl-201) } \\
\text { Pharmacologic stress imaging } \\
\text { (regadenoson, dobutamine, adenosine, } \\
\text { dipyridamole) }\end{array}$ & $\begin{array}{l}\text { Evaluates exercise-related functional status with }>10 \text { metabolic equivalents of work being } \\
\text { excellent prognosis; imaging identifies fixed and reversible ischemia; large zones of reversible } \\
\text { ischemia call for anti-ischemic therapy and additional evaluation usually with angiography; } \\
\text { stress echocardiography gives all the baseline information of resting echocardiography in ad- } \\
\text { dition to the evaluation of reversible ischemia }\end{array}$ \\
\hline $\begin{array}{l}\text { Cardiac computed tomographic } \\
\text { angiography }\end{array}$ & $\begin{array}{l}\text { Appropriate for the evaluation of chest pain with an uninterpretable stress test; not appropri- } \\
\text { ate for patients with established CAD or ESRD; generates calcium score, can evaluate degree } \\
\text { of lumen stenosis if calcification is not severe; normal result has excellent negative predictive } \\
\text { value for cardiac events; calcium score }>400 \text { usually indicates severe disease on invasive an- } \\
\text { giography, while score of } 0 \text { portends excellent prognosis }\end{array}$ \\
\hline $\begin{array}{l}\text { Coronary angiography } \\
\text { Left ventriculography }\end{array}$ & $\begin{array}{l}\text { Definitive diagnosis of coronary luminal obstruction, left ventricular function, and opportu- } \\
\text { nity for ad hoc PCI }\end{array}$ \\
\hline Resting echocardiography & Test of choice to evaluate diastolic and systolic function, valve disease \\
\hline 24-hour Holter monitor & $\begin{array}{l}\text { Records all beats over } 24 \mathrm{~h} \text {, calculates mean atrial and premature beats per hour ( }>10 \text { abnor- } \\
\text { mal), identifies ST segment shifts, identifies asymptomatic arrhythmias }\end{array}$ \\
\hline Cardiac event monitor & Worn for prolonged periods, patient activates device to record symptomatic arrhythmias \\
\hline Insertable loop recorder & $\begin{array}{l}\text { Subcutaneous, pectoral placement of device which records patient and device detected ar- } \\
\text { rhythmias for approximately } 2 \text { years }\end{array}$ \\
\hline
\end{tabular}

$\mathrm{CAD}=$ Coronary artery disease ESRD = end-stage renal disease $\mathrm{PCI}=$ percutaneous coronary intervention; $\mathrm{Tc}=$ technetium; $\mathrm{Tl}=$ thallium .

In a patient with evidence of an old myocardial infarction by electrocardiography (ECG) or with symptoms that could represent coronary ischemia, the decision to proceed with functional imaging or direct coronary angiography can be based on a variety of factors including severity of CKD and risk for contrast-induced acute kidney injury (CI-AKI) [15]. In a low-risk CVD and severe CKD stage, functional imaging is appropriate. If a large reversible area of ischemia is found, then consideration for coronary angiography and ad hoc percutaneous coronary intervention (PCI) or surgical revascularization is reasonable. However, in a high-risk CVD patient (old myocardial infarction on ECG, high-grade accelerating angina, acute coronary syndrome, or angina with signs of left ventricular dysfunction), despite the risks of CIAKI, it may be appropriate to move directly to angiography with the possibility of ad hoc percutaneous coronary intervention with appropriate prophylactic measures taken for CI-AKI $[16,17]$. Most observational studies have found a risk reduction for cardiovascular mortality with optimal medical therapy and revascularization in patients with CKD, provided the patient can be supported through the CI-AKI and postbypass surgery period [1820].

\section{Valvular Disease}

The two most common forms of cardiac valvular disease in CKD are aortic valve calcification and sclerosis, and mitral annular calcification. In both of these conditions, the uremic milieu of CKD mineral and bone disorder promote accelerated calcification. As in atherosclerosis, the calcification of the valves is not passive, but the result of osteoblastic transformation of resident myofibroblasts in cardiac valvular tissue and the deposition of calcium hydroxyapatite crystals. Elevated phosphorus has been associated with valvular calcification and is the most modifiable potential pathogenic factor in CKD [21, 22]. This condition is readily identified by echocardiog- 
Fig. 2. Myocardial disease processes common to patients with CKD.

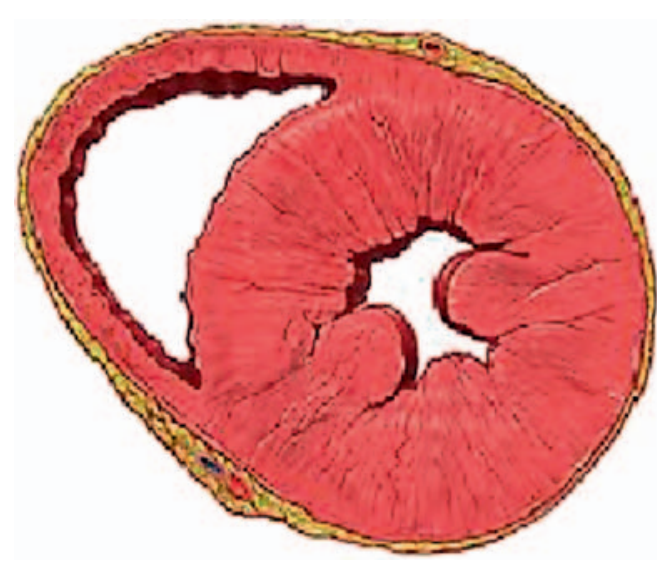

Myocardial changes in CKD

$\uparrow \uparrow$ Collagen/fibrosis

$\uparrow$ Glycated matrix proteins

$\uparrow$ Myocardial calcium

$\uparrow \uparrow$ Left ventricular mass

$\downarrow$ Capillary density

$\downarrow$ Coronary flow reserve

Superimposed injury

-Ischemia

-Infarction

Clinical result

-Diastolic dysfunction

-Systolic dysfunction

-Pump failure death

-Arrhythmic death raphy and rarely causes significant disease of either valve to warrant valve surgery or replacement. The most important clinical implication of valve disease in patients with CKD is the risk for bacterial endocarditis in CKD patients with temporary dialysis catheters either starting or maintaining hemodialysis [23]. A pathologic murmur (grade 2 or higher) should prompt echocardiography in all patients with CKD and there should always be a high suspicion for endocarditis in such patients with fever or other evidence of systemic infection.

\section{Myocardial Disease}

$\mathrm{CKD}$ is recognized as directly inducing changes in the myocardium that result in both diastolic and systolic dysfunction. A common mechanism for the development of myocardial disease appears to be fibrosis (fig. 2). As a part of the aging process, there is dropout of myocardial cells via apoptosis, and increases in the intercellular matrix with advanced glycation end-products and collagen [24]. Over time, a relatively large proportion of the myocardial mass can be composed of cross-linked collagen in the form of fibrotic material [25]. It appears as if CKD may accelerate this process of senescence with the recognizable findings of increased left ventricular mass and Doppler findings of diastolic dysfunction on echocardiography. In a case series of patients with end-stage renal disease undergoing magnetic resonance imaging by Merten et al. [26], 98\% had evidence of myocardial fibro- sis with $36 \%$ in the pattern of prior myocardial infarction and $88 \%$ having some fibrosis present in a nonischemic distribution.

Galectin-3, a blood test recently by the cleared US Food and Drug Administration, is a product of resident macrophages and may be an index of active cardiac fibrosis (table 2). It is prognostic for cardiac hospitalization and death in heart failure patients and is elevated in patients with reduced renal function at baseline [27]. It is too early to develop algorithms for the use of galectin-3 in patients with CKD; however, measurement of blood B-type natriuretic peptide can be used as a diagnostic aid for myocardial disease in patients with CKD, particularly those with clinical signs of possible heart failure [28, 29]. In patients with end-stage renal disease, troponin $\mathrm{T}$ is an approved prognostic aid for mortality in patients measured in an outpatient dialysis center [30]. It is reasonable for all patients with CKD to have an annual ECG with attention to left ventricular hypertrophy. Echocardiography should be performed in any CKD patient with clinical signs of exercise intolerance, fatigue, or findings of volume retention to evaluate both diastolic and systolic dysfunction. While there is controversy over the optimal management of diastolic dysfunction, there are relatively clear objectives in the management of systolic dysfunction, including the use of agents that block the renin-angiotensin-aldosterone system, $\beta$-adrenergic antagonists, and the use of prophylactic cardio defibrillators in those with left ventricular ejection fraction $<35 \%$ [31]. 
Table 2. Select biomarkers for diagnosis, prognosis, and management of CVD in CKD patients

\begin{tabular}{|c|c|}
\hline Test & Comment \\
\hline $\begin{array}{l}\text { Lipid profile (total cholesterol, LDL-C, HDL-C, } \\
\text { triglycerides, non-HDL cholesterol) }\end{array}$ & $\begin{array}{l}\text { All adults and measured at least annually in most patients, indicates risk of MI } \\
\text { and cardiovascular death; LDL-C }<70 \text { and non-HDL-C }<100 \mathrm{mg} / \mathrm{dl} \text { treatment } \\
\text { target for most patients }\end{array}$ \\
\hline $\begin{array}{l}\text { High-sensitivity C-reactive protein, lipoprotein- } \\
\text { associated phospholipase } \mathrm{A}_{2} \text {, myeloperoxidase }\end{array}$ & $\begin{array}{l}\text { Aids in global risk assessment for MI and cardiovascular death in addition to } \\
\text { lipid profile in intermediate-risk patients }\end{array}$ \\
\hline $\begin{array}{l}\text { B-type natriuretic peptide NT-pro B-type } \\
\text { natriuretic peptide }\end{array}$ & $\begin{array}{l}\text { Diagnostic and prognostic aid for heart failure in patients with dyspnea; } \\
\text { prognostic aid in assessment of acute coronary syndromes }\end{array}$ \\
\hline Troponin $\mathrm{T}$ & Prognostic aid for mortality in stable ESRD, correlated with left ventricular mass \\
\hline $\begin{array}{l}\text { Troponin I, troponin } \mathrm{T} \text {, } \\
\text { creatine kinase myocardial band }\end{array}$ & Diagnostic aid in acute MI \\
\hline Galectin-3 & Prognostic aid in heart failure and indicator of myocardial fibrosis \\
\hline
\end{tabular}

\section{Arrhythmias}

Cardiac arrhythmias are largely a reflection of disease in the myocardium. All forms of arrhythmias are increased in patients with CKD [32]. The most common scenario faced is the development of atrial fibrillation [33]. In patients with palpitations, 24-hour and 30-day event recorders are standard means to capture an episode of arrhythmia. Implanted insertable loop recorders can provide surveillance for up to 2 years. Atrial fibrillation for most patients with CKD implies the need for rate control with agents that slow conduction through the atrioventricular node ( $\beta$-adrenergic receptor blockers, calcium channel blockers, digoxin) and for chronic anticoagulation [34]. Most patients with CKD have other components in the CHADS-2 (1 point for congestive heart failure, hypertension, age $\geq 75$ years, diabetes, and 2 points for stroke) score that sum up to $\geq 2$ and call for treatment with warfarin. Dabigatran is a new alternative to warfarin and can be used in CKD (creatinine clearance $15-30 \mathrm{ml} / \mathrm{min}$ ), but at a reduced dose of $75 \mathrm{mg}$ p.o. b.i.d. (usual dose is $150 \mathrm{mg}$ p.o. b.i.d.) [35]. Dabigatran is not recommended in CKD patients with $\mathrm{CrCl}<15 \mathrm{ml} / \mathrm{min}$. Other direct thrombin and factor 10a inhibitors are expected to enter the worldwide market in the next several years and should provide viable strategies to compete with warfarin.

Ventricular arrhythmias are a manifestation of myocardial disease and are statistically more common in
CKD. If sustained ( $>30$ beats) or symptomatic ventricular tachycardia is seen on a session of cardiac monitoring, electrophysiology consultation is warranted. Likewise, a case of resuscitated sudden death with good neurologic outcome should be evaluated by an electrophysiologist. In both circumstances, implantation of a cardioverter defibrillator is commonly indicated with the caveat that patients with CKD commonly have higher defibrillation thresholds, relatively high rates of device utilization, device infection risks if on dialysis, and lower relative risk reductions for all-cause death compared to those with normal renal function [36]. All things considered, if survival is expected to be $>2$ years, ICD implantation for conventional cardiology indications is supportable in patients with CKD and end-stage renal disease [37].

\section{Summary}

The diagnosis of CVD in CKD is important because early recognition of disease can call for intensification of therapy to reduce cardiovascular events including myocardial infarction, hospitalization, and death. It is very common to have cardiovascular diagnostic examination reports in the medical records of patients with CKD. Calcification of the coronary arteries represents atherosclerosis and calls for primary prevention measures. High levels of coronary calcium $>400$ units by 
computed tomography make the presence of provocable ischemia likely. Aortic and mitral valvular calcification rarely cause severe valve dysfunction warranting replacement, but commonly provide a set-up for bacterial endocarditis in a CKD patient who develops bacteremia.
Atrial fibrillation is the most common arrhythmia and calls for both rate control and anticoagulation. Finally, serious ventricular arrhythmias call for ICD implantation in most CKD patients, with reasonable durations of expected survival.

\section{References}

-1 McCullough PA: Why is chronic kidney disease the 'spoiler' for cardiovascular outcomes? J Am Coll Cardiol 2003;41:725-728.

$\checkmark 2$ Best PJ, Reddan DN, Berger PB, Szczech LA, McCullough PA, Califf RM: Cardiovascular disease and chronic kidney disease: insights and an update. Am Heart J 2004;148:230242.

-3 McCullough PA, Jurkovitz CT, Pergola PE, McGill JB, Brown WW, Collins AJ, Chen SC, Li S, Singh A, Norris KC, Klag MJ, Bakris GL, KEEP Investigators: Independent components of chronic kidney disease as a cardiovascular risk state: results from the Kidney Early Evaluation Program (KEEP). Arch Intern Med 2007; 167:1122-1129.

4 Li S, Chen SC, Shlipak M, Bakris G, McCullough PA, Sowers J, Stevens L, Jurkovitz C, McFarlane S, Norris K, Vassalotti J, Klag MJ, Brown WW, Narva A, Calhoun D, Johnson B, Obialo C, Whaley-Connell A, Becker $\mathrm{B}$, Collins AJ: Low birth weight is associated with chronic kidney disease only in men. Kidney Int 2008;73:637-642.

5 Agrawal V, Marinescu V, Agarwal M, McCullough PA: Cardiovascular implications of proteinuria: an indicator of chronic kidney disease. Nat Rev Cardiol 2009;6:301311.

6 Levin A, Stevens L, McCullough PA: Cardiovascular disease and the kidney. Tracking a killer in chronic kidney disease. Postgrad Med 2002;11:53-60.

7 Agrawal V, Shah A, Rice C, Franklin BA, McCullough PA: Impact of treating the metabolic syndrome on chronic kidney disease. Nat Rev Nephrol 2009;5:520-528.

$\checkmark 8$ Zalesin KC, McCullough PA: Bariatric surgery for morbid obesity: risks and benefits in chronic kidney disease patients. Adv Chron ic Kidney Dis 2006;13:403-417.

$\checkmark 9$ McCullough PA, Verrill TA: Cardiorenal interaction: appropriate treatment of cardiovascular risk factors to improve outcomes in chronic kidney disease. Postgrad Med 2010; 122:25-34.

-10 Herzog CA, Asinger RW, Berger AK, Charytan DM, Díez J, Hart RG, Eckardt KU, Kasiske BL, McCullough PA, Passman RS, Deloach SS, Pun PH, Ritz E: Cardiovascular disease in chronic kidney disease. A clinical update from Kidney Disease: Improving Global Outcomes (KDIGO). Kidney Int 2011;80:572-586.
-11 Yerkey MW, Kernis SJ, Franklin BA, Sandberg KR, McCullough PA: Renal dysfunction and acceleration of coronary disease. Heart 2004;90:961-966.

12 McCullough PA, Li S, Jurkovitz CT, Stevens L, Collins AJ, Chen SC, Norris KC, McFarlane S, Johnson B, Shlipak MG, Obialo CI, Brown WW, Vassaloti J, Whaley-Connell AT, Brenner RM, Bakris GL, KEEP Investigators: Chronic kidney disease, prevalence of premature cardiovascular disease, and relationship to short-term mortality. Am Heart J 2008;156:277-283.

13 McCullough PA, Agrawal V, Danielewicz E, Abela GS: Accelerated atherosclerotic calcification and Mönckeberg's sclerosis: a continuum of advanced vascular pathology in chronic kidney disease. Clin J Am Soc Nephrol 2008;3:1585-1598.

14 McCullough PA: The impact of systemic calcified atherosclerosis in patients with chronic kidney disease. Adv Chronic Kidney Dis 2008;15:335-337.

15 McCullough PA: Cardiovascular disease in chronic kidney disease from a cardiologist's perspective. Curr Opin Nephrol Hypertens 2004;13:591-600.

16 McCullough PA, Nowak RM, Foreback C Borzak S, Tokarski G, Tomlanovich MC, Khoury NE, Weaver WD, Sandberg KR, McCord J: Performance of multiple cardiac biomarkers measured in the emergency department in patients with chronic kidney disease and chest pain. Acad Emerg Med 2002;9: 1389-1396.

$\checkmark 17$ Keeley EC, McCullough PA: Coronary revascularization in patients with coronary artery disease and chronic kidney disease. Adv Chronic Kidney Dis 2004;11:254-260.

-18 McCullough PA, Sandberg KR, Borzak S, Hudson MP, Garg M, Manley HJ: Benefits of aspirin and beta-blockade after myocardial infarction in patients with chronic kidney disease. Am Heart J 2002;144:226-232.

$>19$ Keeley EC, Kadakia R, Soman S, Borzak S, McCullough PA: Analysis of long-term survival after revascularization in patients with chronic kidney disease presenting with acute coronary syndromes. Am J Cardiol 2003;92: 509-514

20 McCullough PA, Verrill T: Lessons learned from acute myocardial infarction in patients with chronic kidney disease. J Intern Med 2010;268:38-39.
21 Tarrass F, Benjelloun M, Zamd M, Medkouri G, Hachim K, Benghanem MG, Ramdani B: Heart valve calcifications in patients with end-stage renal disease: analysis for risk factors. Nephrology (Carlton) 2006;11:494-496.

22 Linefsky JP, O’Brien KD, Katz R, de Boer IH, Barasch E, Jenny NS, Siscovick DS, Kestenbaum B: Association of serum phosphate levels with aortic valve sclerosis and annular calcification the cardiovascular health study. J Am Coll Cardiol 2011;58:291-297.

$>23$ Nucifora G, Badano LP, Viale P, Gianfagna P, Allocca G, Montanaro D, Livi U, Fioretti PM: Infective endocarditis in chronic haemodialysis patients: an increasing clinical challenge. Eur Heart J 2007;28:2307-2312.

24 Thomas MC: Advanced glycation end products. Contrib Nephrol 2011;170:66-74.

25 Biernacka A, Frangogiannis NG: Aging and cardiac fibrosis. Aging Dis 2011;2:158-173.

26 Merten C, Merbach C, Schwenger V, Zeier M, Katus HA, Giannitsis E, Steen H: 2077 Detection and differentiation of myocardial delayed contrast enhancement patterns by cardiac MRI in patients with end stage renal disease. J Cardiovasc Magn Reson 2008; 10(suppl 1):A34.

27 Tang WH, Shrestha K, Shao Z, Borowski AG, Troughton RW, Thomas JD, Klein AL: Usefulness of plasma galectin-3 levels in systolic heart failure to predict renal insufficiency and survival. Am J Cardiol 2011;108:385-390.

28 McCullough PA, Nowak RM, McCord J, Hollander JE, Herrman HC, Steg PG, Duc P, Westheim A, Omland T, Wold Knudsen C, Storrow AB, Abraham WT, Lamba S, Wu AHB, Perez A, Clopton P, Krishnaswamy P, Kazanegra R, Maisel AS, BNP Multinational Study Investigators: B-type natriuretic peptide and clinical judgment in the emergency diagnosis of heart failure: an analysis from the Breathing Not Properly (BNP) Multinational Study. Circulation 2002;106:416-422.

-29 McCullough PA, Duc P, Omland T, McCord J, Nowak RM, Hollander JE, Herrmann HC, Steg PG, Westheim A, Knudsen CW, Storrow AB, Abraham WT, Lamba S, Wu AH, Perez A, Clopton P, Krishnaswamy P, Kazanegra R, Maisel AS, Breathing Not Properly Multinational Study Investigators: B-type natriuretic peptide and renal function in the diagnosis of heart failure: an analysis from the Breathing Not Properly Multinational Study. Am J Kidney Dis 2003;41:571-579. 
-30 Mallamaci F, Zoccali C, Parlongo S, Tripepi G, Benedetto FA, Cutrupi S, Bonanno G, Fatuzzo P, Rapisarda F, Seminara G, Stancanelli B, Bellanuova I, Cataliotti A, Malatino LS: Troponin is related to left ventricular mass and predicts all-cause and cardiovascular mortality in hemodialysis patients. Am J Kidney Dis 2002;40:68-75.

-31 Chronic kidney disease: tipping the scale to the benefit of angiotensin-converting enzyme inhibitors in patients with coronary artery disease. Circulation 2006;114:6-7.

- 32 Soman SS, Sandberg KR, Borzak S, Hudson MP, Yee J, McCullough PA: The independent association of renal dysfunction and arrhythmias in critically ill patients. Chest 2002;122:669-677.
33 Alonso A, Lopez FL, Matsushita K, Loehr LR, Agarwal SK, Chen LY, Soliman EZ, Astor $\mathrm{BC}$, Coresh J: Chronic kidney disease is associated with the incidence of atrial fibrillation: the Atherosclerosis Risk in Communities (ARIC) Study. Circulation 2011;123: 2946-2953.

-34 Fuster V, Rydén LE, Cannom DS, Crijns HJ, Curtis AB, Ellenbogen KA, Halperin JL, Kay GN, Le Huezey JY, Lowe JE, Olsson SB, Prystowsky EN, Tamargo JL, Wann LS: 2011 ACCF/AHA/HRS focused updates incorporated into the ACC/AHA/ESC 2006 Guidelines for the management of patients with atrial fibrillation: a report of the American College of Cardiology Foundation/American Heart Association Task Force on Practice Guidelines developed in partnership with the European Society of Cardiology and in collaboration with the European Heart Rhythm Association and the Heart Rhythm Society. J Am Coll Cardiol 2011;57:e101e198.
35 Blommel ML, Blommel AL: Dabigatran etexilate: a novel oral direct thrombin inhibitor. Am J Health Syst Pharm 2011;68:15061519.

36 Wase A, Basit A, Nazir R, Jamal A, Shah S, Khan T, Mohiuddin I, White C, Saklayen M, McCullough PA: Impact of chronic kidney disease upon survival among implantable cardioverter-defibrillator recipients. J Interv Card Electrophysiol 2004;11:199204

37 McCullough PA, Sandberg KR: Chronic kidney disease and sudden death: strategies for prevention. Blood Purif 2004;22:136142 . 